\title{
Biologically-Derived Material
}

National Cancer Institute

\section{Source}

National Cancer Institute. Biologically-Derived Material. NCI Thesaurus. Code C43376.

Natural substances derived from living org anisms such as cells, tissues, proteins, and DNA. 